\title{
Does Political and Economic Freedom Matter for Inbound Tourism? A Cross-National Panel Data Estimation
}

\author{
Shrabani Saha, Jen-Je Su, and Neil Campbell
}

\begin{abstract}
The paper examines the impact of political and economic freedom on inbound tourism for over 110 countries during 1995-2012. Panel country fixed-effects techniques are utilized to examine the relationship after controlling for other factors that contribute to inbound tourism. The results show that civil liberties and economic freedom (among several other freedom measures) are positively and significantly associated with inbound tourism. Examination of the moderation effect reveals that civil liberties (economic freedom) tend to play a more influential role on inbound tourism when the level of economic freedom (civil liberties) is relatively low.
\end{abstract}

Keywords: Political freedom, economic freedom, tourism, panel data 


\section{Introduction}

Tourism is a large and rapidly growing sector in the world economy. In 2014 international tourist arrivals were recorded at 1138 million (UNWTO 2015). The UNWTO goes on to note that this 2014 figure represents the fifth year of consecutive strong growth. Taleb Rifai, UNWTO Secretary-General, argues that the tourism sector has strongly contributed to international economic recovery as well as providing millions of jobs throughout the world (UNWTO 2015). In particular, tourism is very effective at providing employment and small business opportunities in developing countries and hence, to some extent, counters the problems of chronic underemployment and unemployment.

Given the importance of the tourism industry, examining what factors appeal inbound tourism constantly claims researchers' attention. Commonly, inbound tourism studies have mainly focused on economic and political factors such as national income, exchange rates, travel costs and political (in)stability - see, for example, Crouch 1994, Turner and Witt 2001, Neumayer 2004, Prideaux 2005, Lim 2006, Yap and Saha 2013, and De Vita 2014. More recently, many other relevant factors are also well explored in the inbound tourism literature: for instance, travel risk (Fischhoff et al. 2004); tourist worry (Larsen et al. 2009); heritage sites (Su and Lin 2014); cultural similarity (Cheung and Saha 2015) and corruption (Saha and Yap 2015). However, surprisingly, only very few empirical studies have looked into the influence of institutional factors (such as political and economic freedom) on inbound tourism. Das and Dirienzo 2009 investigate the relationship between global tourism competitiveness and freedom of the press, but the paper is silent about how this relationship may affect inbound tourism. Gholipour et al. 2014, on the other hand, examines the influence of personal/political freedom on outbound tourism, but they do not probe how personal/political freedom might affect international tourist arrivals as well. Su and Lin 2014, 
to our knowledge, is the only study that includes political freedom as one of the control variables in modelling inbound tourism - nevertheless, since political freedom is not the main concern of their paper, its role in inbound tourism is largely unexplored. Moreover, none of these papers have considered another institutionally-based freedom, that is, economic freedom as a potential factor explaining inbound tourism.

In this paper, we aim to fill the research gap by studying the impacts of political and economic freedom on inbound tourism. To this end, we first empirically examine the individual effect of political and economic freedom on attracting international tourists by employing panel data. We then explore the combined and moderation effects between these two freedoms. Specifically, by incorporating an interaction term for these two freedom variables, we are able to quantify the impact of political freedom (economic freedom) at the different levels of economic freedom (political freedom). Thus we take an innovative approach, separating the multiple effects on inbound tourism.

Our basic hypothesis is that those countries which have a higher level of political (economic) freedom will have higher inbound tourism. Our interest in the role of freedom on inbound tourism was, at least partially, sparked by the work of Gholipour et al. 2014 on the role of freedom in outbound tourism. They contend that if personal freedom is scarce in a country, people will value it more, which results in a higher level of demand for personal freedom. Therefore, if people's personal freedom is suppressed people may search for their own personal freedom in other countries through traveling. A corollary of this is that countries with higher levels of personal freedom will attract more international tourists. Additionally, it is reasonable to contend, that there would be tourists who are used to living in countries with high levels of personal freedom and hence prefer to have holidays in countries with such levels of freedom. With economic freedom, it has the capability to make a 
country's tourism industry more competitive which, in turn, brings in more tourists (see Das and Dirienzo 2009).

We also argue that whether a country has strong political freedom or strong economic freedom - either way it will do better in attracting tourists than if it had neither of these attributes. While, from a liberal view point, it is obviously desirable to have both political and economic freedom these objectives cannot be achieved instantly even by altruistic policy makers. If, for example, economic reforms can be achieved faster than political reforms, then we argue that these economic reforms by themselves will have a tendency to increase number of international tourists. For instance, think of the growth of tourism following the economic reforms in China (see Lew 2001).

This study analyses the impact of political and economic freedom on inbound tourism by using panel data techniques for over 110 countries for the period 1995-2012. The panel fixed effects technique is utilized in handling the potential endogeneity owing to the unobserved country fixed effects. We also use the moderation (interaction) effect technique to estimate the impacts of political and economic freedom on inbound tourism. ${ }^{1}$ Hence, one of the objectives of this paper is to develop an inbound tourism model that can capture the impacts of interaction between these two freedom variables on tourism businesses. The model can then generate more accurate estimations of tourism demand for the purposes of forecasting and planning effective strategies.

The rest of the paper is organised as follows. The next section outlines a theoretical perspective followed by a data description, an empirical strategy and the results. In the final section the conclusions are presented.

\section{Theoretical Background}


Apart from the occasional hermit kingdom, governments actively promote their tourism sector. This support can be rationalized using the standard market failure paradigm. That is, tourist developments and promotions have positive externalities. Government support can also be understood in terms of political economy considerations. The tourism sector typically has the potential to employ large numbers of semi-skilled workers, often outside the main metropolitan areas. Hence the factors that cause tourists to choose between destinations are clearly of interest to policy makers, and, this interest can be clearly understood in terms of mainstream economic theory.

At first glance it might seem obvious that increases in all freedoms (whether political or economic) would make a destination more attractive to tourists. However, it needs to be remembered that tourists are not immigrants. A tourist might enjoy the benefits of living in a liberal democracy, but be happy to visit a ‘tourist friendly’ dictatorship. ${ }^{2}$ Alternatively, a tourist might make a moral choice to avoid visiting a reviled dictatorship such as Myanmar prior to the recent reforms. The apparent dichotomy between the amoral and moral tourist is muddied by the risk-conscious tourist who believes that dictatorships and illiberal democracies $^{3}$ are inherently riskier countries to visit. Putting aside the fear of an unexpected explosion in political violence, a tourist might fear falling foul of an arbitrary, corrupt and ineffectual law enforcement/judicial system. Even where such a system takes a tolerant view of misbehaving tourists (drunken and rowdy behaviour) there is the concern that some dispute with an influential local might result in a harsh penalty. In addition, a police 'crack down’ may result in tourists being penalized for trivial offences ${ }^{4}$ or for being in the wrong place at the wrong time. We regard tourists being concerned about 'getting into trouble' with an illiberal regime as an issue associated with a lack of civil liberties rather than a lack of political rights. The basic political rights such as the right to vote and the right to form political parties exist in both liberal and illiberal democracies. However, with illiberal 
democracies there is an inherent lack of civil liberties because there are not the institutions (such as a free press and independent judiciary) to defend such liberties. On the other hand, lack of economic freedom has the potential to negatively impact on the 'tourist experience' since economic freedom allows entrepreneurs to provide a broad range of tourist services. When competition is allowed to work there is a strong incentive not to provide poor and disinterested service. So our contention is that civil liberties and economic freedom will attract tourists, but political rights (the distinguishing factor between an authoritarian regime and an illiberal democracy) will typically not have a significant effect upon tourist demand (with countries like Myanmar being something of an exception). We further contend that whether a country has strong civil liberties or strong economic freedom - either way it will do better at attracting tourists than if it had neither of these attributes.

Commenting further on the role of economic freedom we note that Barro and Sala-iMartin 2004, Knack and Keefer 1995, Mauro 1995, Dawson 1998, and Easton and Walker 1997 argue that an economically free nation produces a more competitive business environment by providing an established and stable legal and monetary system, efficient labour and product markets, and open trade and investment opportunities. In this context, Saha et al. 2009 finds that a higher level of economic freedom can reduce a country’s level of corruption. In other words, economic freedom lowers corruption by increasing competition. Furthermore, Saha and Yap 2015 examine the relationship between corruption and tourism and the study concludes that the number of tourist arrivals decline in the most corrupt countries. These two studies, considered jointly, imply that a higher level of economic freedom can make the tourism industry more competitive and reduce the level of corrupt which in turn attracts more tourists. ${ }^{5}$

To make this discussion more concrete, let's start by considering the case of Singapore. Singapore is an illiberal democracy in that it has regular parliamentary elections, but there are 
restrictions on freedoms of association and assembly, there are restrictions on the media and, in general, there is a lack of freedom of speech, and serious questions have arose with regard to the independence (or lack of independence) of the judiciary (see Freedom House 2014). However, unlike the stereotype chaotic illiberal democracy Singapore is a well-ordered society with low crime rates and a lack of petty corruption. ${ }^{6}$ It has a very high level of economic freedom; however, the government is quite active in taking specific economic initiatives.

The development of integrated resorts (resorts that include casinos) is an example of the Singaporean Government taking policy decisions so as to promote tourism (see MTI 2012). The Government invited proposals for each development. The developer that won the contract for the Marina Bay resort was Las Vegas Sands (LVS). Part of the motivation for the Government to go down this path appears to be a bid to grow tourism (and compete with rival destinations) by rebranding Singapore as a more permissive society:

“The Singapore government chose Las Vegas Sands (LVS) among four international bidders for the right to build the first of Singapore's two "integrated resorts", which will include casinos. Prime Minister Lee Hsien Loong, son of national patriarch and current government Minister Mentor Lee Kuan Yew, took the leap of legalizing casino gambling last year in a bid to rebrand Singapore as an edgy, with-it city, as opposed to the straitlaced, do as you're told, get rid of the chewing gum model of successful urban autocracy.”

LaMoshi 2006.

We can see from this quote from 2006 the idea that it is in a country's self-interest to present a liberal face to the world and offer an experience for visitors (both tourist and business) that is free from the oppressive hand of government. Nevertheless, Singapore is a prime example of a country with limited civil liberties, but a high level of economic freedom and this, 
combined with an effective state, has facilitated a strong tourist industry. This fits with our hypothesis that either strong civil liberties or economic freedom can effectively facilitate growth in tourism. Singapore's development model which features economic freedom has allowed it to grow into a high-income country with excellent services for tourists.

Now let's turn to the example of Malta. This is a country with good civil liberties, but only moderate economic freedom. While Malta is an attractive tourist destination, there are problems with the services that are available to tourists:

“Too many waiters show over-familiarity with customers. Others have no clue of proper service. Some, probably engaged for short periods, do not even know what they have on the menu. Some places do not serve wine or beer in the correct glass.” Times of Malta 2014.

The Heritage Foundation regards the labour market in Malta as being relatively rigid. ${ }^{7}$ It is reasonable to contend that greater economic freedom would, to some degree, improve tourist services. However, overall, Malta offers an attractive combination of attributes to a large number of tourists; it has sun, sand and a rich and exotic history, and, it also offers the safety of good civil liberties.

Finally we turn to considering the case of Myanmar. We argue that this case is an exception in that, to some extent, lack of political rights has had a direct effect on the demand for tourism (see Henderson 2003, 104). However, there were other factors. These include the concerns tourists would have had about their civil liberties given the regime's reputation for being capricious, paranoid and xenophobic. In addition there would have been tourist concerns about civil unrest breaking out. Also, there was the issue of an under developed tourist infrastructure. While the regime (by the 1990s) welcomed foreign investment in tourist accommodation, its reputation (and the country’s reputation for internal turmoil) limited such investment. Foreign investors were also discouraged by pressure from human 
rights organisations and western governments (see Hobson and Leung 1997). With the recent democratic reforms Myanmar has shed its pariah status. While compared with many of its neighbours Myanmar's tourist numbers are quite small, they have dramatically increased with a reported tripling since 2012 (see Kyaw 2014). For the past two decades the regime in Myanmar had wanted to grow the tourist industry, but it was only with the recent reforms that the tourist numbers dramatically jumped. These reforms caused improvements in political rights, civil liberties and economic freedom. Since the pre-reforms political repression in Myanmar had made it an international cause célèbre, in this special case the internationally recognized improvement in political rights clearly were significant in encouraging tourism.

\section{Model, Data and Methodology}

This section discusses the model, data and the methodology used in examining the impact of political and economic freedom on inbound tourism.

\section{Model}

The main purpose of this study is to explore the effects of political freedom and economic freedom on inbound tourism. In the first step, we examine the impact of political and economic freedom individually on inbound tourism via the following panel data model:

$$
\ln \left(I T_{i t}\right)=\theta_{t}+\beta X_{i t}+Z_{i t}^{\prime} \gamma+v_{i}+e_{i t}
$$

where IT is inbound tourism; $X$ is either political freedom or economic freedom; $Z$ represents a set of standard control variables discussed in the next section; $\theta_{t}$ allows for different years intercept (year effects); $v_{i}$ contains time-invariant effect (fixed country effects); $e_{i t}$ is the error term; $i$ is country; $t$ is year. The parameter $\beta$ is of interest as it measures the partial effect of 
political or economic freedom, holding $Z$ fixed. We hypothesize that $\beta$ is positive - that is, a high level of political or economic freedom increases international tourist numbers arriving in a country.

Secondly, we examine the moderation effects of political and economic freedom on inbound tourism. ${ }^{8}$ The moderation effects of political and economic freedom (PF and EF, respectively) measures how PF and EF work together in shaping inbound tourism. Equation (2) incorporates the moderation effects in the base equation (1):

$\ln \left(I T_{i t}\right)=\theta_{t}+\beta_{1} P F_{i t}+\beta_{2} E F_{i t}+\beta_{3} P F_{i t} * E F_{i t}+Z_{i t}^{\prime} \gamma+v_{i}+e_{i t}$.

In equation (2), PF, EF and their interaction are considered at the same time. The marginal impacts of PF and EF on international tourist numbers are calculated as follows:

$$
\begin{aligned}
& \frac{\partial \ln \left(I T_{i t}\right)}{\partial P F_{i t}}=\beta_{1}+\beta_{3} E F_{i t}, \\
& \frac{\partial \ln \left(I T_{i t}\right)}{\partial E F_{i t}}=\beta_{2}+\beta_{3} P F_{i t} .
\end{aligned}
$$

Clearly, the coefficient $\beta_{3}$ captures the interaction effect of PF and EF. Given that $\beta_{1}, \beta_{2}>0$, if $\beta_{3}>0$, equations 3(a) and 3(b) imply that the effect of PF (EF) on inbound tourism is greater as EF (PF) increases; conversely, if $\beta_{3}<0$, the effect of PF (EF) is smaller as EF (PF) increases. We hypothesize that $\beta_{3}<0$; that is, for example, increase in PF will be more (less) influential at promoting inbound tourism as EF decreases (increases), and vice versa.

\section{Data}

This subsection discusses the variables used in the study and their data sources. 


\section{Dependent variables}

We consider four different measures of inbound tourism - namely, tourism arrivals (TA), tourism arrivals per capita (TAPC), tourism receipts (TR), and tourism receipts per capita (TRPC). TA is the total number of international tourist arrivals (in thousands) to a country in a given year; TR is the total international tourism income (in million U.S. dollars) of a country in a given year; TAPC and TRPC are obtained using TA and TR divided by the country's population, respectively. The relevant data are extracted from the World Bank and Euromonitor International, covering over 110 countries from 1995 to 2012. ${ }^{9}$ The number of countries selected for this study is based on the availability of data for most of the variables.

\section{Independent variables}

For the purpose of this study three different political freedom variables are used. First, we utilize Freedom House civil liberties (CL) and political rights (PR) data as political freedom variables. According to the definition provided by Freedom House, CL allow for the freedoms of expression and belief, associational and organizational rights, rule of law, and personal autonomy without interference from the state and PR enable people to participate freely in the political process, including the right to vote freely for distinct alternatives in legitimate elections, compete for public office, join political parties and organizations, and elect representatives who have a decisive impact on public policies and are accountable to the electorate. The scale for CL and PR is assigned a numerical rating on a scale of 1 to $7-\mathrm{a}$ rating of 7 indicates the highest degree of freedom and 1 the lowest. ${ }^{10}$ The third political freedom measure is democratic accountability (DA) which is obtained from the International Country Risk Guide of the Political Risk Services (PRS) Group. It is a measure of how responsive government is to its citizens and it is more likely that less responsive governments 
will fall, peacefully in a democratic society, but possibly violently in a non-democratic one. The score for this democracy index is rescaled, ranging from zero to 6 with higher values signaling a higher degree of democracy. With regard to economic freedom, two variables EF and EFW - are used. EF, the Index of Economic Freedom, is sourced from the Heritage Foundation; it measures the level of regulations on economic activities in a country. ${ }^{11} \mathrm{EFW}$ is the Economic Freedom of the World index published by the Fraser Institute; it is based on personal choice, voluntary exchange, freedom to compete, and security of privately owned property. Both EF and EFW are scaled from 0 to 10, where 10 represent the maximum level of economic freedom. ${ }^{12}$

\section{Control variables}

To ensure the model estimations are unbiased and reliable, a set of five variables are used as the control variables. They are (i) real gross domestic product per capita in logarithmic form (ln(GDPPC)) (ii) real exchange rate in the US dollar in logarithmic form ( $\ln (\mathrm{EXCHR}))(\mathrm{iii})$ bureaucratic quality (BQ) (iv) external conflict (EC) (v) government stability (GS). ${ }^{13}$ The literature on tourism destinations’ competitiveness regards economic development as the crucial factor for strengthening human resources and infrastructure (see Das and Dirienzo 2009). Enright and Newton 2004 and 2005 find strong empirical support for the inclusion of destination attributes in studies of tourism competitiveness and a country's overall economic condition is an important consideration for tourists. While exploring the determinants of tourism revenue and length of stay, economic development has been used by Kara et al. 2003 and Garín-Munoz and Amaral 2000. Moreover, Das and Dirienzo 2009, Saha and Yap 2014, and Saha and Yap 2015 use GDP per capita as a proxy for economic development in estimating inbound tourism demand in a cross-country framework. Following the above literature this study incorporates the real GDP per capita from the World Bank as a proxy for 
economic development. In addition, the human development index (HDI) is used as a measure of economic development (instead of real GDP per capita) for a robustness check. However, it is important to note that this is not to be confused with demand models which use the source country’s GDP as a proxy for income. Real exchange rate is a common control variable in tourism models (see Lim 2006, Saha and Yap 2014, and Cheung and Saha 2015). The real EXCHR measures the national currency prices in terms of US dollars that are adjusted by purchasing power parity (PPP) over GDP. According to Lim 2006, EXCHR reflects the relative tourism prices between source and destination countries. When a destination's currency depreciates, the travel cost in the destination will be cheaper, and hence more international travelers are expected to visit the destination. To check for robustness the exchange rate and the inflation rate are considered (instead of the real exchange rate).

In addition, three more control variables - GS, EC and BQ - are used to distinguish the political stability of each destination. They are obtained from Political Risk Services (PRS) International Country Risk Guide (ICRG) political instability indicators. ${ }^{14}$ GS and EC are measured in a scale of 0 to 12 whereas, BQ is from 0 to 4 and a higher value of these indices represents more stable government, greater conflict and better quality, respectively. Since political stability plays an important role in determining destination choice, these three variables may have a considerable influence on tourism demand Yap and Saha 2013. The descriptive statistics of all the variables and pairwise correlations among independent and control variables under study are reported in appendix Table A1 and Table A2, respectively.

\section{Estimation Methodology}

This paper applies panel data techniques to estimate the relationships between political/economic freedom and inbound tourism specified in equations (1) and (2). 
According to Baltagi 2008 and Wooldridge 2009, panel data models are advantageous over models with cross-sectional or time-series data because panel data allows researchers to control for time-invariant country heterogeneity that cannot be done when time-series or cross-sectional data are used. Not controlling this heterogeneity runs the risk of obtaining biased results (see Moulton 1986 and Moulton 1987).

Two estimation techniques - namely, random effects (RE) estimation and fixed effects (FE) estimation - are routinely applied to panel data models. Between these two estimation techniques, the major advantage of FE over RE is that it avoids omitted variables bias owing to the probable correlation between the independent variables and the omitted variables, as long as the omitted variables are time-invariant (e.g. culture, location, historical heritage). Since it is hard to rule out such bias a priori (for example, political/economic freedom and culture are very likely to be correlated), FE is the preferred estimation method in this study. ${ }^{15}$ It is important to note here that we are not trying to emphasize that culture is driven by institutional freedoms. When we say, political/economic freedom and culture are very likely to be correlated, what we mean is that the level of freedom (for concreteness think of civil liberties) can be affected by cultural attitudes toward freedom (think of a collectivist culture verses an individualist culture). However, if the omitted variables are unrelated to the independent variables, then RE and FE are both consistent and RE is more efficient (see Baltagi 2008 and Wooldridge 2009). ${ }^{16}$ Also, to adjust for the potential heteroskedasticity, serial correlation and cluster dependence, the inference results are based on robust standard errors.

The results from fixed (random) effects models may be affected by endogeneity problems. For example, we assumed that economic development measured by real GDP per capita increases destinations' competitiveness and as a result increases the number of international tourists visiting a country. However, this positive relationship can be explained the other way 
around through tourism-led-growth. This form of endogeneity of explanatory variables is simultaneity. This arises when one or more of the explanatory variables are jointly determined with the dependent variable (see Wooldridge 2009). The endogeneity problem can be solved by applying instrumental variable methods such as generalized method of moments (GMM) (Gholipour et al. 2014). For robustness purposes, following Arellano and Bond 1991, we estimate GMM for endogeneity of GDPPC using the following external instruments: lagged saving (percentage of GDP), investment (percentage of GDP) and secondary school enrolment.

\section{Empirical Results}

This section discusses the empirical results of our analysis. The first part of the analysis focuses on the impacts of political and economic freedom on inbound tourism with control variables. The second part analyses the moderation effects of political and economic freedom on inbound tourism for all countries. The final part discusses the partial effects of political and economic freedom on inbound tourism. Both country and period fixed effects (i.e. twoway FE) are employed in all the analysis for the period 1995-2012.

To start with, the regression fit of the scatter plots shown in Figure 1 and Figure 2 represents the relationship between civil liberties and economic freedom with tourist arrivals (TA). The log of tourist arrival per capita is measured on the $Y$-axis in both the figures and civil liberties (CL) and economic freedom (EF) are on the $X$-axes in Figure 1 and Figure 2, respectively. The regression fit lines for civil liberties and economic freedom are upward sloping, indicating that civil liberties and economic freedom are positively correlated with tourist arrivals per capita. In other words, high civil liberties and economic freedom bring more international tourists to a country. 


\section{[FIGURE 1 AND FIGURE 2 ABOUT HERE]}

To explore the relationship in more detail we first start our analysis with tourist arrivals (TA) as the dependent variable based on equation (1). The FE results for TA are reported in Table 1. Columns (1)-(3) show the results for three different measures of the political freedom variable and their impact on TA. The coefficient for civil liberties (CL) in column (1) is positive and significant at the $5 \%$ level indicating that a higher level of civil liberties in a country would encourage more people to travel to that country from other countries. ${ }^{17}$ Specifically, the regression result shows that when CL is up by one scale, holding other factors unchanged, tourist arrivals will increase by $7.39 \% .{ }^{18}$ On the other hand, while the effects of other political freedom measures such as democratic accountability (DA) and political rights (PR) are positive, none of them is significant (columns (2)-(3), Table 1). The result suggests that civil liberties are more crucial than other forms of political freedom in attracting foreign tourists. Likewise, Table 1 shows that the effect of economic freedom (EF) is positive and significant, and a one scale rise in EF is associated with 9.85\% increase in TA. ${ }^{19}$ A similar effect is found with the other economic freedom measure (EFW) (column (5)). Tourist arrivals after controlling for country size (TAPC) produces very similar results shown in columns (6)-(10) (Table 1). Overall, these results support our hypothesis that political (specifically, civil rights) and economic freedom would boost a country’s inbound tourism. Besides, in Table 1, while some of the control variables are statistically insignificant, they all show the expected signs. Real GDP per capita and depreciation of currency increases international tourists' arrivals as the coefficients of $\ln (\mathrm{GDPPC})$ and $\ln (\mathrm{EXCHR})$ are positive ${ }^{20}$ Countries with a low currency (a favourable exchange rate) attract more tourists. In addition, political instability variables are all consistent and as expected with regard to their signs. A higher level of bureaucratic quality and government stability increases the 
inbound tourism for a country. On the other hand, external conflict has a negative and significant impact on inbound tourism, meaning that an increase in external conflict in a country decreases international travelers' demand for visiting such destinations. This is in line with previous studies on determinants of inbound tourism (e.g. Saha and Yap 2014 and Yap and Saha 2013).

\section{[TABLE 1 ABOUT HERE]}

Table 2 reports the results when tourism revenue (TR) is the dependent variable (columns (1)-(5)). The coefficients for political and economic freedom variables retain the similar signs and significance level for political and economic freedom in terms of tourism revenue. However, the magnitudes of the CL and EF coefficients are greater for TR, i.e. a one unit increase in CL and EF increases TR by $9.69 \%$ and $12.3 \%$, respectively. Interestingly, DA is significant when TR is the dependent variable. The impact on tourism revenue per capita (TRPC) again illustrates similar results in columns (6)-(10) (Table 2). Overall, both civil liberties and economic freedoms consistently show positive influence in increasing tourism demand for a country. These two variables, plus the control factors, explain more than $50 \%$ of the variations in inbound tourism across countries.

\section{[TABLE 2 ABOUT HERE]}

\section{Moderation Effects of Political and Economic Freedom on Inbound Tourism}

This subsection discusses the results of the moderation effects of political and economic freedom on inbound tourism based on equation (2). The above results confirm that among the three measures of political freedom, only civil liberties (CL) consistently show positive and 
significant impacts on inbound tourism along with both measures of economic freedom (EF and EFW). Hence, the focus of the moderation effect is the interaction term between CL and EF/EFW and its influence on inbound tourism. To save space, we only report the estimation results with the interaction between $\mathrm{CL}$ and $\mathrm{EF} .^{21}$ The fixed effects estimation results for tourism arrival and tourism revenue are reported in Table 3.

In columns (1), (3), (5) and (7) of Table 3, the coefficients of both CL and EF are all positive and significant when different measures of inbound tourism are used as the dependent variable. The result shows that when the two freedom variables are included in the inbound tourism function at the same time the individual positive effect endures as in Tables 1 and 2. However, this linear setting is unable to incorporate the moderation effect. In columns (2), (4), (6) and (8), the moderation effect is specified by including an interaction term $\left(C L^{*} E F\right)$. The estimation results show that the coefficients of the interaction term are all negative and well significant (at the $1 \%$ level) in all cases. As stated in the previous section, a negative interaction effect of CL and EF implies that the effect of CL (EF) is smaller as EF (CL) increases. Based on equation (2a), taking column 2 for example, the partial effect of CL on TA is positive only if EF is lower than 0.637/0.095 = 6.71 (e.g. South Africa and UAE); on the other hand, the effect of EF is positive only if CL is lower than 0.408/0.095=4.29 (e.g. Israel and Greece). In other words, the effect of CL (EF) is the highest when EF (CL) is low. Accordingly, the negative interaction effect of CL and EF might ultimately make any increase of CL and/or EF damage inbound tourism when EF and CL are already at high levels.

To examine the robustness of our results we run through various model specifications; the results are not reported here due to space limitations. ${ }^{22}$ The non-linear effects of CL and EF on inbound tourism are also tested by adding the square terms of CL and EF and the moderation effects results remain the same even after including the square terms in the model 
specification. ${ }^{23}$ It is important to note that the moderation effects between CL and EF remain the same sign and significant even after excluding the real GDP per capita which may cause the endogeneity problem. ${ }^{24}$ Moreover, incorporating HDI as a different measure of economic development and inflation does not alter our main finding regarding the moderation effect of CL and EF. ${ }^{25}$ Finally, GMM results after controlling for endogeneity of real GDP per capita confirm the moderation effect results discussed above. ${ }^{26}$

\section{[TABLE 3 ABOUT HERE]}

We further explore the partial effects of CL (EF) on tourism demand at various levels of EF (CL) and report the results in Table 4 (5). ${ }^{27}$ In Table 4, CL significantly increases inbound tourism, but in a diminishing manner till EF reaches between 6 and 7 . When EF $\geq 7$, the effect of CL is no longer positive and becomes insignificant. Likewise, as shown in Table 5, the partial effect of EF decreases as CL increases and the effect is no longer positive and significant when $\mathrm{CL} \geq 4$.

[TABLE 4 AND TABLE 5 ABOUT HERE]

\section{Conclusion}

In this article, we examined the influence of political and economic freedom on the performance of the tourism industry, in terms of tourist arrivals and tourism receipts, for over 110 countries for the period 1995-2012, by using panel data estimation techniques. The results show that political freedom has a favourable effect on inbound tourism, however, among the three political freedom measures considered, only civil liberties show consistent and significant positive impacts on tourism (and the magnitude of the effect is considerable). By facilitating personal freedom and safety from arbitrary persecution, civil liberties are able 
to attract more international tourists into a country. After using several indicators and specifications, this effect was shown to be robust. Likewise, economic freedom enhances tourism for all measures of inbound tourism. The results show similar effects for alternative economic freedom measures. This result is consistent with economic theory which predicts the removal of restrictions will reduce rent-seeking behaviour and facilitate an improvement in services as individuals respond to incentives. Hence, more freedom expands a country’s tourism industry. The results for control variables are also consistent with the theory; that is, a higher real GDP per capita and a currency depreciation encourage more tourists to visit a country. In addition, a higher level of bureaucratic quality, government stability and less external conflict increase the number of tourists and the revenue from the tourism industry.

The moderation effect results reveal that civil liberties (economic freedom) produce positive effects on inbound tourism at the mean score of economic freedom (civil liberties); however, the effects decrease when economic freedom (civil liberties) is high. In other words, the effect of CL (EF) is the highest when EF (CL) is low. The partial interaction effects of civil liberties and economic freedom provide interesting insights to identify the impact on inbound tourism at various levels of freedom. In comparison, civil liberties significantly increase inbound tourism up to the economic freedom index between 6 and 7 and after the threshold level the effect is no longer positive. On the other hand, the threshold level of economic freedom is between 3 and 4 of the civil liberties index and after that level the effect of economic freedom decreases when the value of the civil liberties index increases. The moderation effects suggest that any type of freedom either political or economic freedom can cause a strengthening in the inbound tourism.

The policy implications of our results need to be considered with the proviso that policy makers cannot simply 'pull a lever' and instantly have improved levels of civil liberties and/or economic freedom. With civil liberties reforms, these are unlikely to be primarily, or 
even significantly, motivated by the desire to improve inbound tourism. Civil liberties reforms will only be fully effective over quite a period of time. For example, consider institutional reforms that, in a legal sense, make the judiciary fully independent. Here it may take decades for some judicial attitudes to change. That is, some judges may retain the mindset associated with the illiberal state, for example, believing it is right, proper and patriotic to always believe the police and take direction from the government. While economic reforms can have a rapid effect as entrepreneurs take advantages of new opportunities, gaining sufficient political consensus to implement such reforms may well be a time consuming process. Nevertheless it is plausible to contend that in many cases economic reform will have more of a comparatively short run impact than reforms to enhance civil liberties. In such a situation, a reformist government, motivated by the desire to facilitate economic growth and heal social divisions, may act to put in place reforms to establish improvements in economic and political freedom, and, expect benefits from increased tourism demand in the shorter run (because of increased economic freedom) and in the longer run (because of improved civil liberties).

\section{References}

Aiken, L. S., and S. G. West. 1991. Multiple Regression: Testing and Interpreting Interactions. Thousand Oaks, CA: Sage.

Arellano, M., and S. R. Bond. 1991. "Some Tests of Specification for Panel Data: Monte Carlo Evidence and an Application to Employment Equations.” Review of Economic Studies, 58(2): 277-97.

Baltagi, B. H. 2008. Econometric Analysis of Panel Data. West Sussex: Wiley. 
Barro, R. J. and X. Sala-i-Martin. 2004. Economic Growth. 2nd ed. Cambridge, Massachusetts: MIT Press.

BBC. 2008. “Tourists warned of UAE drug laws.” BBC News, 8 February. http://news.bbc.co.uk/2/hi/uk_news/7234786.stm

Cheung, Y. H. and S. Saha. 2015. "Exploring the Nexus between Tourism Demand and Cultural Similarity.” Tourism Analysis 20: 229-241.

Crouch, G. I. 1994. "The study of international tourism demand: a review of findings.” Journal of Travel Research 33 (1): 12-23.

Das, J., and C. Dirienzo. 2009. “Global Tourism Competitiveness and Freedom of the Press: A Nonlinear Relationship.” Journal of Tourism Research 47 (4): 470-79.

Dawson, J. W. 1998. "Institutions, investment and growth: New cross-country and panel data evidence.” Economic Inquiry 36 (4): 603-619.

De Viata, G. 2014. “The long-run impact of exchange rate regimes on international tourism flows.” Tourism Management 45: 226-233.

Easton, S. T., and M. A. Walker. 1997. “Income, Growth, and Economic Freedom.” American Economic Review 87 (2): 328-332. 
Enright, M. J. and J. Newton. 2004. “Tourism destination competitiveness: a quantitative approach.” Tourism Management 25 (6): 777-788.

Enright, M. J. and J. Newton. 2005. “Determinants of Tourism Destination Competitiveness in Asia Pacific: Comprehensiveness and Universality.” Journal of Travel Research 43 (4): 339-350.

Freedom House. 2014. “Singapore: Freedom in the World 2014.” Freedom House Website. https://freedomhouse.org/report/freedom-world/2014/singapore-0 (accessed July 13, 2015).

Fischhoff, B., W. B. De Bruin, W. Perrin and J. Downs. 2004. “Travel Risks in a Time of Terror: Judgments and Choices.” Risk Analysis 24 (5): 1301-1309.

Garín-Munoz, T., and T. P. Amaral 2000. “An Econometric Model for International Tourism Flows to Spain.” Applied Economic Letters, 7 (8): 525-29.

Gholipour, H. F., R. Tajaddini, and U. Al-mulali. 2014. "Does personal freedom influence outbound tourism?” Tourism Management. 41: 19-25.

Halcoussis, D. 2005. Understanding Econometrics. Cincinnati, OH: Thomson South-Western. Henderson, J. 2003. “The Politics of Tourism in Myanmar.” Current Issues in Tourism 6 (2): 97-118. 
Heritage Foundation. 2015. “2015 Index of Economic Freedom: Malta.” Heritage Foundation Website. http://www.heritage.org/index/country/malta (accessed July 13, 2015).

Hobson, P., and R. Leung. 1997. "Hotel Development in Myanmar: Politics and the HumanResources Challenge.” Cornell Hotel and Restaurant Administration Quarterly 38 (1): 60-71.

Kara, A., M. Tarim, and E. Tatoglu 2003. “The Economic, Social, and Environmental Determinants of Tourism Revenue in Turkey: Some Policy Implications.” Journal of Economic and Social Research, 5(2): 61-72.

Knack, S., and P. Keefer. 1995 “Institutions and economic performance: institutional measures cross-country tests using alternative institutional measures.” Economics and Politics 7 (3): 207-227.

Kyaw, H. M. 2014. “Amid Burma Tourism Boom, Calls for Govt to Aid Development.” Irrawaddy, 6 January. http://www.irrawaddy.org/burma/amid-burma-tourism-boom-callsgovt-aid-development.html

LaMoshi, G. 2006. “Singapore makes an honest bet.” Asia Times Online, 31 May. http://www.atimes.com/atimes/Southeast_Asia/HE31Ae01.html

Larsen, S., W. Brun, and T. Øgaard. 2009. "What tourists worry about - Construction of a scale measuring tourist worries.” Tourism Management 30 (2): 260-265. 
Lew, A. 2001. "Tourism Development in China: The Dilemma of Bureaucratic

Decentralization and Economic Liberalization.” In Tourism and the Less Developed World:

Issues and Case Studies, edited by D. Harrison, 109-120. Wallingford, UK: CABI Publishing.

Lim, C. 2006. “A survey of tourism demand modeling practice: Issues and implications.” In International handbook on the economics of tourism, edited by L. Dwyer and P. Forsyth, 4572. Northampton, U.K.: Edward Elgar Publishing.

Mauro, P. 1995. “Corruption and Growth.” Quarterly Journal of Economics 110 (3): 681-712.

Merrill, D. 2009. Negotiating Paradise: U.S. Tourism and Empire in Twentieth-Century Latin America. Chapel Hill, NC: The University of North Carolina Press.

Moulton, B.R. 1986. "Random Group Effects and the Precision of Regression Estimates.” Journal of Econometrics 32 (3): 385-397.

Moulton, B.R. 1987. “Diagnostics for Group Effects in Regression Analysis.” Journal of Business and Economic Statistics 5 (2): 275-282.

MTI. 2012. “MTI Insights: Integrated Resorts.” MTI Website, 9 July. http://www.mti.gov.sg/MTIInsights/Pages/Integrated\%20Resorts.aspx

Myrdal, G. 1970. “The ‘Soft State’ in Undeveloped Countries”. In Unfashionable Economics: Essays in Honour of Lord Balogh, edited by P. Streeten, London: Weidenfeld and Nicolson. 
Neumayer, E. 2004. “The impact of political violence on tourism.” Journal of Conflict Resolution 48 (2): 259-281.

Prideaux, B. 2005 "Factors affecting bilateral tourism flows." Annals of Tourism Research 32 (3): 780-801.

Saha, S., R. Gounder, and J. J. Su. 2009. "The Interaction Effect of Economic Freedom and Democracy on Corruption: A Panel Cross-Country Analysis." Economics Letters 105 (2): 173-76.

Saha, S., and G. Yap. 2014. "The moderation effects of political instability and terrorism on tourism development: A cross-country panel analysis.” Journal of Travel Research 53 (4): 509-521.

Saha, S., and G. Yap. 2015. “Corruption and tourism: an empirical investigation in a nonlinear framework.” International Journal of Tourism Research 17 (3): 272-281.

Su, Y. W., and H. L. Lin. 2014. “Analysis of international tourist arrivals worldwide: The role of world heritage sites.” Tourism Management 40: 46-58.

Times of Malta. 2014. “Tourism: problems that never go away.” Times of Malta Website, 3 April. http://www.timesofmalta.com/articles/view/20140403/editorial/Tourism-problemsthat-never-go-away.513347 
Turner, L. W., and S. F. Witt. 2001. "Factors influencing demand for international tourism: tourism demand analysis using structural equation modelling, revisited.” Tourism Economics 7 (1): 21-38.

UNWTO. 2015. “Over 1.1 billion tourists travelled abroad in 2014.” UNWTO World Tourism Barometer 13(1): 1-6.

http://dtxtq4w60xqpw.cloudfront.net/sites/all/files/pdf/unwto_barom15_01_january_excerpt 1.pdf (accessed June 18, 2015).

Wooldridge, J. M. 2009. Introductory econometrics: A modern approach. 4th ed. Canada: South-Western.

Yap, G., and S. Saha. 2013. "Do political instability, terrorism, and corruption have deterring effects on tourism development even in the presence of UNESCO heritage? A cross-country panel estimate.” Tourism Analysis 18 (5): 587-599. 
Table 1. Effects of Political Freedom and Economic Freedom on International Tourism Arrivals

\begin{tabular}{|c|c|c|c|c|c|c|c|c|c|c|}
\hline & (1) & (2) & (3) & (4) & (5) & (6) & (7) & (8) & (9) & (10) \\
\hline & $\ln (\mathrm{TA})$ & $\ln (\mathrm{TA})$ & $\ln (\mathrm{TA})$ & $\ln (\mathrm{TA})$ & $\ln (\mathrm{TA})$ & $\ln ($ TAPC) & $\ln (\mathrm{TAPC})$ & $\ln (\mathrm{TAPC})$ & $\ln ($ TAPC) & $\ln$ (TAPC) \\
\hline \multirow[t]{2}{*}{$\ln ($ GDPPC) } & $0.419 *$ & $0.464 * *$ & $0.458 * *$ & $0.359 *$ & 0.319 & $0.713 * * *$ & $0.751^{* * *}$ & $0.745^{* * *}$ & $0.645 * * *$ & $0.651 * * *$ \\
\hline & $(0.058)$ & $(0.039)$ & $(0.041)$ & $(0.097)$ & $(0.101)$ & $(0.000)$ & $(0.000)$ & $(0.000)$ & $(0.000)$ & $(0.000)$ \\
\hline \multirow[t]{2}{*}{$\ln (\mathrm{EXCHR})$} & 0.0439 & 0.0422 & 0.0422 & 0.0449 & 0.00742 & 0.0461 & 0.0447 & 0.0445 & 0.0474 & 0.0179* \\
\hline & $(0.274)$ & $(0.307)$ & $(0.302)$ & $(0.253)$ & $(0.585)$ & $(0.127)$ & $(0.152)$ & $(0.150)$ & $(0.101)$ & $(0.054)$ \\
\hline \multirow[t]{2}{*}{ Bureau Quality (BQ) } & $0.113^{*}$ & 0.0901 & 0.100 & 0.0974 & 0.0636 & 0.0915 & 0.0713 & 0.0807 & 0.0779 & 0.0483 \\
\hline & $(0.069)$ & $(0.143)$ & $(0.108)$ & $(0.114)$ & $(0.282)$ & $(0.123)$ & $(0.222)$ & $(0.175)$ & $(0.184)$ & $(0.396)$ \\
\hline \multirow[t]{2}{*}{ External Conflict (EC) } & $-0.0416 * * *$ & $-0.0437 * * *$ & $-0.0455^{* * *}$ & $-0.0418 * * *$ & -0.0147 & $-0.0259 *$ & $-0.0274^{*}$ & $-0.0295^{*}$ & $-0.0257^{*}$ & -0.00172 \\
\hline & $(0.009)$ & $(0.008)$ & $(0.005)$ & $(0.005)$ & $(0.370)$ & $(0.080)$ & $(0.074)$ & $(0.050)$ & $(0.061)$ & $(0.912)$ \\
\hline \multirow[t]{2}{*}{ GOVT Stability (GS) } & $0.0256^{* *}$ & $0.0252^{* *}$ & $0.0255^{* *}$ & $0.0261^{* *}$ & 0.0105 & $0.0158 *$ & $0.0155^{*}$ & $0.0157^{*}$ & $0.0166 *$ & 0.00393 \\
\hline & $(0.017)$ & $(0.016)$ & $(0.016)$ & $(0.016)$ & $(0.272)$ & $(0.084)$ & $(0.081)$ & $(0.082)$ & $(0.067)$ & $(0.631)$ \\
\hline \multirow[t]{2}{*}{ Civil Liberties (CL) } & $0.0739 * *$ & & & & & $0.0624 * *$ & & & & \\
\hline & $(0.026)$ & & & & & $(0.047)$ & & & & \\
\hline \multirow[t]{2}{*}{ Democratic Accountability (DA) } & & 0.0248 & & & & & 0.0236 & & & \\
\hline & & $(0.198)$ & & & & & $(0.187)$ & & & \\
\hline \multirow[t]{2}{*}{ Political Rights (PR) } & & & 0.00865 & & & & & 0.00437 & & \\
\hline & & & $(0.635)$ & & & & & $(0.807)$ & & \\
\hline \multirow[t]{2}{*}{ Economic Freedom (EF) } & & & & 0.0985* & & & & & $0.102 * *$ & \\
\hline & & & & $(0.058)$ & & & & & $(0.029)$ & \\
\hline
\end{tabular}




\begin{tabular}{|c|c|c|c|c|c|c|c|c|c|c|}
\hline & & & & & $(0.015$ & & & & & $(0.028)$ \\
\hline Adjusted R-squared & 0.596 & 0.592 & 0.591 & 0.603 & 0.608 & 0.516 & 0.513 & 0.511 & 0.526 & 0.525 \\
\hline No. of Observations & 1883 & 1883 & 1883 & 1863 & 1376 & 1868 & 1868 & 1868 & 1848 & 1363 \\
\hline No. of Countries & 111 & 111 & 111 & 111 & 109 & 110 & 110 & 110 & 110 & 108 \\
\hline
\end{tabular}

Notes: (i) Regression results are based on equation (1), using both year and country fixed effects; (ii) ln(*) stands for natural log; (iii) dependent variables: TA - tourism

arrivals; TAPC - tourism arrivals per capita; (iv) independent variable: GDPPC - real GDP per capita; EXCHR - real exchange rate; others are as the names shown; and (v)

$P$-values (based on the robust standard errors) are in the parentheses; ${ }^{*} \mathrm{p}<0.10,{ }^{* *} \mathrm{p}<0.05, * * * \mathrm{p}<0.01$. 
Table 2. Effects of Political Freedom and Economic Freedom on International Tourism Receipts

\begin{tabular}{|c|c|c|c|c|c|c|c|c|c|c|}
\hline & (1) & (2) & (3) & (4) & (5) & (6) & (7) & (8) & (9) & (10) \\
\hline & $\ln (\mathrm{TR})$ & $\ln (\mathrm{TR})$ & $\ln (\mathrm{TR})$ & $\ln (\mathrm{TR})$ & $\ln (\mathrm{TR})$ & $\ln (\mathrm{TRPC})$ & $\ln (\mathrm{TRPC})$ & $\ln (\mathrm{TRPC})$ & $\ln (\mathrm{TRPC})$ & $\ln (T R P C)$ \\
\hline \multirow[t]{2}{*}{$\ln ($ GDPPC) } & $1.056^{* * *}$ & $1.111^{* * *}$ & $1.102 * * *$ & $0.939 * * *$ & $0.691^{*}$ & $1.314^{* * *}$ & $1.362 * * *$ & $1.353^{* * *}$ & $1.184 * * *$ & $0.981 * * *$ \\
\hline & $(0.001)$ & $(0.000)$ & $(0.001)$ & $(0.002)$ & $(0.055)$ & $(0.000)$ & $(0.000)$ & $(0.000)$ & $(0.000)$ & $(0.001)$ \\
\hline $\ln ($ EXCHR) & $0.0488 * * *$ & $0.0466 * * *$ & $0.0458 * * *$ & $0.0483^{* * *}$ & $0.0354^{*}$ & $0.0484 * * *$ & $0.0464 * * *$ & $0.0452 * * *$ & $0.0483 * * *$ & $0.0434 * *$ \\
\hline \multirow[t]{2}{*}{ Bureau Quality (BQ) } & 0.101 & 0.0678 & 0.0838 & 0.0805 & $0.140^{*}$ & 0.0795 & 0.049 & 0.0638 & 0.0604 & 0.120 \\
\hline & $(0.175)$ & $(0.394)$ & $(0.279)$ & $(0.300)$ & $(0.088)$ & $(0.276)$ & $(0.525)$ & $(0.399)$ & $(0.424)$ & $(0.131)$ \\
\hline \multirow{3}{*}{ External Conflict (EC) } & - & - & $-0.0662 * * *$ & $-0.0587 * * *$ & -0.00633 & $-0.0454 * *$ & $-0.0459 * *$ & $-0.0511 * *$ & $-0.0433 * *$ & 0.00617 \\
\hline & $0.0606 * * *$ & $0.0614 * * *$ & & & & & & & & \\
\hline & $(0.005)$ & $(0.005)$ & $(0.002)$ & $(0.001)$ & $(0.733)$ & $(0.033)$ & $(0.032)$ & $(0.014)$ & $(0.014)$ & $(0.754)$ \\
\hline \multirow[t]{2}{*}{ GOVT Stability (GS) } & 0.0144 & 0.0138 & 0.014 & 0.0117 & 0.0127 & 0.00577 & 0.0053 & 0.00544 & 0.00365 & 0.00738 \\
\hline & $(0.327)$ & $(0.343)$ & $(0.329)$ & $(0.397)$ & $(0.335)$ & $(0.662)$ & $(0.686)$ & $(0.674)$ & $(0.764)$ & $(0.536)$ \\
\hline \multirow[t]{2}{*}{ Civil Liberties (CL) } & $0.0969 * *$ & & & & & $0.0857 *$ & & & & \\
\hline & $(0.037)$ & & & & & $(0.056)$ & & & & \\
\hline \multirow[t]{2}{*}{ Democratic Accountability (DA) } & & $0.0442 *$ & & & & & $0.0412 *$ & & & \\
\hline & & $(0.057)$ & & & & & $(0.080)$ & & & \\
\hline \multirow[t]{2}{*}{ Political Rights (PR) } & & & 0.00278 & & & & & -0.00366 & & \\
\hline & & & $(0.939)$ & & & & & $(0.918)$ & & \\
\hline Economic Freedom (EF) & & & & $0.123 * *$ & & & & & $0.134 * * *$ & \\
\hline
\end{tabular}




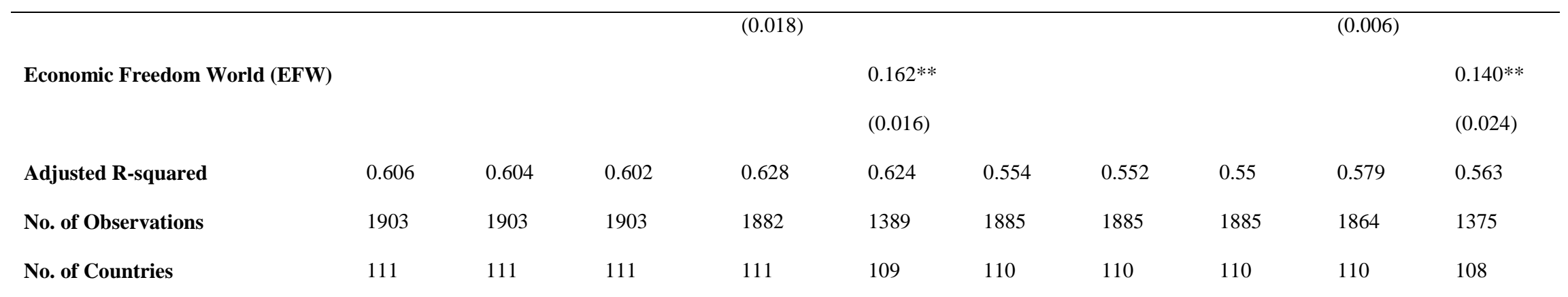

Notes: (i) Regression results are based on equation (1), using both year and country fixed effects; (ii) ln(*) stands for natural log; (iii) dependent variables: TR - tourism

receipts; TRPC - tourism receipts per capita; (iv) independent variables: GDPPC - real GDP per capita; EXCHR - real exchange rate; others are as the names shown; and (v)

$P$-values (based on the robust standard errors) are in the parentheses; ${ }^{*} \mathrm{p}<0.10,{ }^{* *} \mathrm{p}<0.05, * * * \mathrm{p}<0.01$. 
Table 3. Moderation Effects of Political Freedom and Economic Freedom on Tourism Arrivals and Receipts

\begin{tabular}{|c|c|c|c|c|c|c|c|c|}
\hline & (1) & (2) & (3) & (4) & (5) & (6) & (7) & (8) \\
\hline & $\ln (\mathrm{TA})$ & $\ln (\mathrm{TA})$ & $\ln$ (TAPC) & $\ln (\mathrm{TAPC})$ & $\ln (\mathrm{TR})$ & $\ln (\mathrm{TR})$ & $\ln (\mathrm{TRPC})$ & $\ln (T R P C)$ \\
\hline \multirow[t]{2}{*}{$\ln ($ GDPPC) } & 0.330 & 0.218 & $0.621 * * *$ & $0.546^{* * *}$ & $0.904 * * *$ & $0.792 * * *$ & $1.154^{* * *}$ & $1.078^{* * *}$ \\
\hline & $(0.125)$ & $(0.275)$ & $(0.000)$ & $(0.001)$ & $(0.002)$ & $(0.007)$ & $(0.000)$ & $(0.000)$ \\
\hline \multirow[t]{2}{*}{$\ln ($ EXCHR) } & 0.0469 & 0.0399* & $0.0491 *$ & $0.0444 * *$ & $0.0515^{* * *}$ & $0.0432 * *$ & $0.0512 * * *$ & $0.0457 *$ \\
\hline & $(0.226)$ & $(0.082)$ & $(0.084)$ & $(0.015)$ & $(0.000)$ & $(0.037)$ & $(0.000)$ & $(0.060)$ \\
\hline \multirow[t]{2}{*}{ Bureau Quality (BQ) } & $0.111^{*}$ & $0.134 * *$ & 0.0896 & $0.106^{*}$ & 0.100 & $0.120 *$ & 0.0778 & 0.0915 \\
\hline & $(0.072)$ & $(0.023)$ & $(0.128)$ & $(0.064)$ & $(0.180)$ & $(0.092)$ & $(0.287)$ & $(0.194)$ \\
\hline \multirow[t]{2}{*}{ External Conflict (EC) } & $-0.0362 * *$ & $-0.0232 *$ & -0.021 & -0.0118 & $-0.0514^{* * *}$ & $-0.0391 * *$ & $-0.0369 * *$ & -0.028 \\
\hline & $(0.012)$ & $(0.081)$ & $(0.105)$ & $(0.349)$ & $(0.004)$ & $(0.032)$ & $(0.035)$ & $(0.127)$ \\
\hline \multirow[t]{2}{*}{ GOVT Stability (GS) } & $0.0258 * *$ & $0.0213^{* *}$ & $0.0164 *$ & 0.013 & 0.0114 & 0.00766 & 0.00332 & 0.000487 \\
\hline & $(0.017)$ & $(0.031)$ & $(0.074)$ & $(0.137)$ & $(0.417)$ & $(0.579)$ & $(0.789)$ & $(0.969)$ \\
\hline \multirow[t]{2}{*}{ Civil Liberties (CL) } & $0.0766 * *$ & $0.637 * * *$ & $0.0639 * *$ & $0.458 * * *$ & $0.106^{* *}$ & $0.694 * * *$ & $0.0931 * *$ & $0.503 * * *$ \\
\hline & $(0.016)$ & $(0.000)$ & $(0.032)$ & $(0.001)$ & $(0.011)$ & $(0.000)$ & $(0.021)$ & $(0.001)$ \\
\hline \multirow[t]{2}{*}{ Econ Freedom (EF) } & $0.0860 *$ & $0.408^{* * *}$ & $0.0912^{* *}$ & $0.315^{* * *}$ & $0.106^{* *}$ & $0.450 * * *$ & $0.118^{* *}$ & $0.354 * * *$ \\
\hline & $(0.093)$ & $(0.000)$ & $(0.048)$ & $(0.000)$ & $(0.035)$ & $(0.000)$ & $(0.011)$ & $(0.000)$ \\
\hline \multirow[t]{2}{*}{$\mathbf{C L} * \mathbf{E F}$} & & $-0.0950 * * *$ & & $-0.0667 * * *$ & & $-0.0984 * * *$ & & $-0.0686 * * *$ \\
\hline & & $(0.000)$ & & $(0.002)$ & & $(0.000)$ & & $(0.003)$ \\
\hline Adjusted R-squared & 0.609 & 0.636 & 0.532 & 0.550 & 0.634 & 0.648 & 0.584 & 0.593 \\
\hline No. of Observations & 1863 & 1848 & 1848 & 1882 & 1882 & 1864 & 1864 & 1863 \\
\hline
\end{tabular}


Notes: (i) Regression results are based on equation (2), using both year and country fixed effects; (ii) ln(*) stands for natural log; (iii) dependent variables: TA - tourism arrivals; TAPC - tourism arrivals per capita; TR - tourism receipts; TRPC - tourism receipts per capita; (iv) independent variable: GDPPC - real GDP per capita; EXCHR real exchange rate; $C L * F E$ - the interaction term of Civil Liberties (CL) and Economic Freedom (EF); others are as the names shown; and (v) $P$-values (based on the robust standard errors) are in the parentheses; ${ }^{*} \mathrm{p}<0.10,{ }^{* *} \mathrm{p}<0.05$, *** $\mathrm{p}<0.01$. 
Table 4. Partial Effects of Civil Liberties (CL) at Various Levels of Economic Freedom (EF)

\begin{tabular}{|c|c|c|c|c|}
\hline \multicolumn{5}{|c|}{ Civil Liberties } \\
\hline & $\ln (\mathrm{TA})$ & $\ln$ (TAPC) & $\ln (T R)$ & $\ln (\mathrm{TRPC})$ \\
\hline \multirow[t]{2}{*}{$E F=3$} & $0.352^{* * *}$ & $0.258 * * *$ & $0.398 * * *$ & $0.298 * * *$ \\
\hline & $(0.000)$ & $(0.001)$ & $(0.000)$ & $(0.001)$ \\
\hline \multirow[t]{2}{*}{$E F=4$} & $0.257 * * *$ & $0.191^{* * *}$ & $0.300^{* * *}$ & $0.229 * * *$ \\
\hline & $(0.000)$ & $(0.001)$ & $(0.000)$ & $(0.001)$ \\
\hline \multirow[t]{2}{*}{$E F=5$} & $0.162^{* * *}$ & $0.125^{* * *}$ & $0.202^{* * *}$ & $0.161^{* * *}$ \\
\hline & $(0.000)$ & $(0.001)$ & $(0.000)$ & $(0.001)$ \\
\hline \multirow[t]{2}{*}{$E F=6$} & $0.0673 * *$ & $0.0581^{* *}$ & $0.103^{* *}$ & $0.0921^{* *}$ \\
\hline & $(0.027)$ & $(0.044)$ & $(0.014)$ & $(0.022)$ \\
\hline \multirow[t]{2}{*}{$E F=7$} & -0.0277 & -0.00861 & 0.00470 & 0.0235 \\
\hline & $(0.445)$ & (0.798) & (0.914) & $(0.576)$ \\
\hline \multirow[t]{2}{*}{$E F=8$} & $-0.123^{* *}$ & -0.0753 & $-0.0937 *$ & -0.0451 \\
\hline & (0.019) & $(0.122)$ & (0.089) & $(0.407)$ \\
\hline
\end{tabular}

Notes: (i) The estimated effects are based on equation (3a); and (ii) $P$-values in the parentheses; * $\mathrm{p}<0.10$, ** $\mathrm{p}<0.05, * * * \mathrm{p}<0.01$. 
Table 5. Partial Effects of Economic Freedom (EF) at Various Levels Civil Liberties (CL)

\begin{tabular}{|c|c|c|c|c|}
\hline \multicolumn{5}{|c|}{ Economic Freedom } \\
\hline & $\ln (\mathrm{TA})$ & $\ln (\mathrm{TAPC})$ & $\ln (T R)$ & $\ln (T R P C)$ \\
\hline \multirow[t]{2}{*}{$\mathrm{CL}=1$} & $0.313^{* * *}$ & $0.248 * * *$ & $0.352 * * *$ & $0.286 * * *$ \\
\hline & $(0.000)$ & $(0.000)$ & $(0.000)$ & $(0.000)$ \\
\hline \multirow[t]{2}{*}{$C L=2$} & $0.218^{* * *}$ & $0.182 * * *$ & $0.253 * * *$ & $0.217 * * *$ \\
\hline & $(0.000)$ & $(0.001)$ & $(0.000)$ & $(0.000)$ \\
\hline \multirow[t]{2}{*}{$C L=3$} & $0.123^{* * *}$ & $0.115 * * *$ & $0.155^{* * *}$ & $0.149 * * *$ \\
\hline & $(0.007)$ & $(0.009)$ & $(0.002)$ & $(0.002)$ \\
\hline \multirow[t]{2}{*}{$C L=4$} & 0.0277 & 0.0482 & 0.0563 & $0.0802 *$ \\
\hline & $(0.527)$ & $(0.277)$ & $(0.215)$ & $(0.083)$ \\
\hline \multirow[t]{2}{*}{$C L=5$} & -0.0673 & -0.0185 & -0.0421 & 0.0117 \\
\hline & $(0.205)$ & $(0.734)$ & $(0.421)$ & $(0.832)$ \\
\hline \multirow[t]{2}{*}{$C L=6$} & $-0.162^{* *}$ & -0.0852 & $-0.140 * *$ & -0.0569 \\
\hline & $(0.019)$ & $(0.224)$ & $(0.034)$ & $(0.420)$ \\
\hline
\end{tabular}

Notes: (i) The estimated effects are based on equation (3b); and (ii) $P$-values in the parentheses; * $\mathrm{p}<0.10,{ }^{* *}$ $\mathrm{p}<0.05, * * * \mathrm{p}<0.01$. 
Figure 1. The Relationship between Tourism Arrivals and Political Freedom (Civil Liberties) - Average 1995-2012

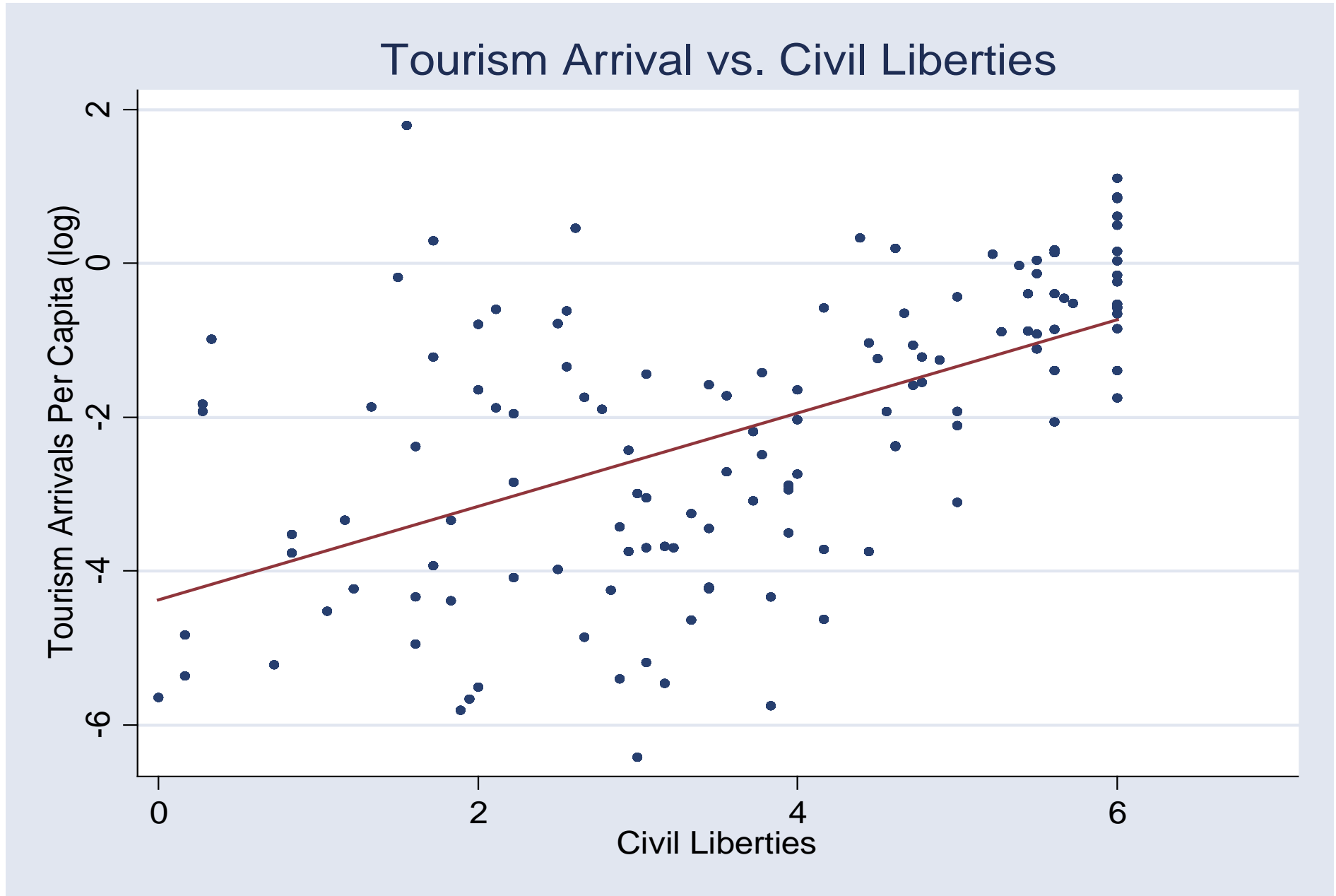


Figure 2. The Relationship between Tourism Arrivals and Economic Freedom - Average 1995-2012

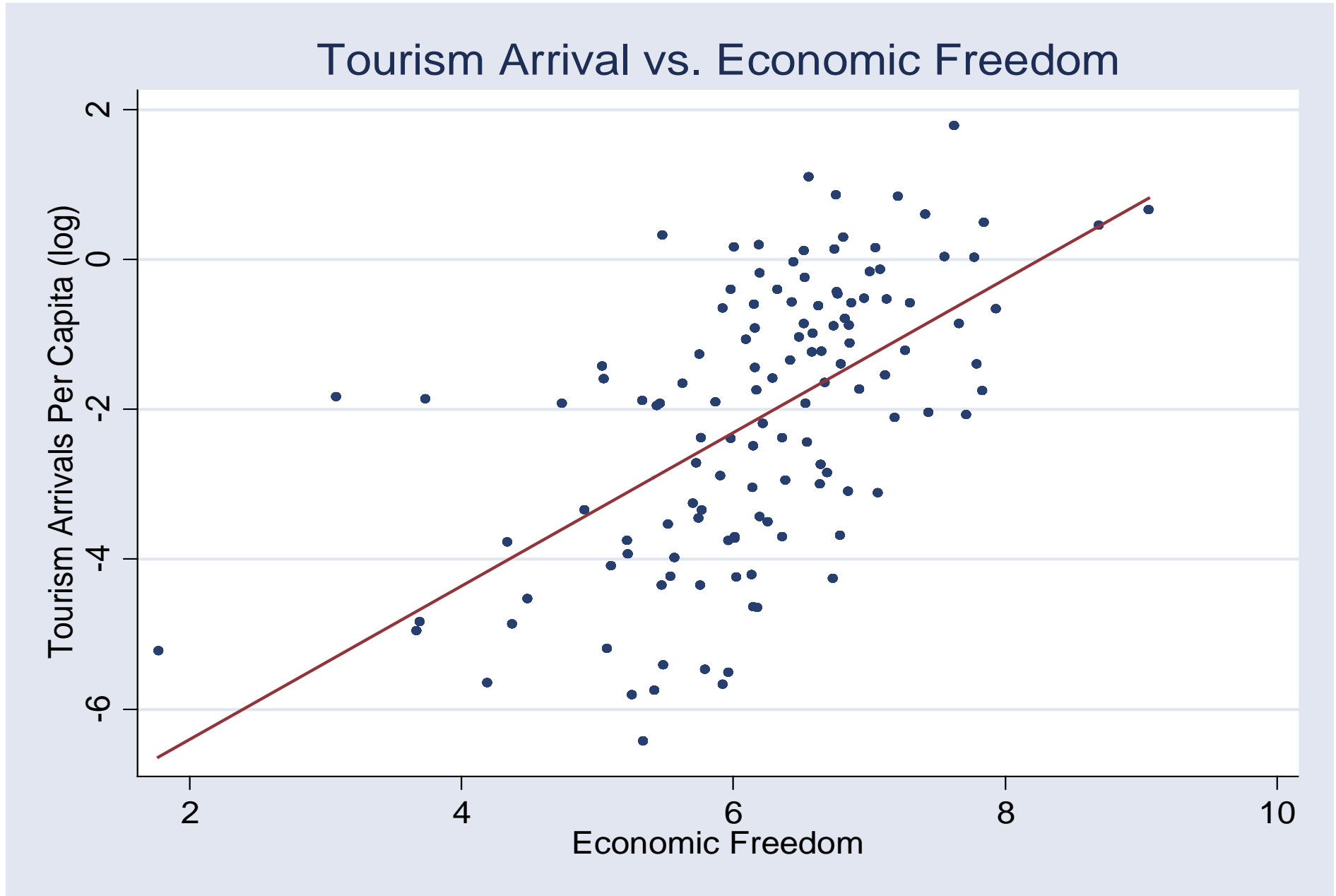




\section{Endnotes}

1. See Saha and Yap 2014 for the moderation effects.

2. Batista's Cuba of the 1950's is an example of a dictatorship where tourism thrived (see Merrill 2009). Of course, in context of the Cold War the average US tourist would have had considerable sympathy for the fervently anti-communist Fulgencio Batista.

3. We use the terms illiberal democracy and electoral democracy interchangeably. Here we are referring to a situation where there is more-orless free and fair elections, but the institutions associated with a liberal democracy (such as an independent judiciary) are not in place.

4. The BBC 2008 discusses the example of the UAE where tourists face harsh penalties for having tiny amounts of cannabis on their shoes or having undocumented over-the-counter painkillers.

5. The benefit of competition is revealed quantitatively by the reduction in the costs of tourism products; qualitative improvements in the quality of tourism products are harder to measure.

6. While Myrdal's 1970 term 'the soft state' tends to mean different things to different people, the Singaporean state is 'hard' rather than 'soft' when it comes to the ability to control institutions' and individuals' behavior.

7. See Heritage Foundation 2015 for details.

8. Moderation effects measure the combined effects of independent variables on a dependent variable. Rather than focusing on the effects of a single independent variable, the analysis can combine effects of two or more independent variables (see Aiken and West 1991 and Halcoussis 2005). 
9. TA and TR are from the World Bank (from 1995 to 2012) but countries with data apparently inconsistent with those of the Euromonitor (since 2000) are deleted.

10. Originally, a rating of 7 indicates the lowest degree of freedom and 1 the highest. To ease the interpretation, CL and PR are rescaled by reverse ordering.

11. EF is based on ten equally weighted individual freedoms: business freedom, trade freedom, monetary freedom, freedom from government, fiscal freedom, property right, investment freedom and financial freedom. We exclude the freedom from corruption component from the original economic freedom index as corruption is related to some of our control variables.

12. Until 2000, the EFW index was available only once every five years (starting from 1975). In this study, as with the other variables, the EFW index is from 1995 to 2012, but with a gap between 1996 and 1999.

13. Internal conflict is not incorporated as a control variable because it is very likely that internal conflict is absorbed by government stability.

14. ICRG is a well-known and widely used dataset in the economics literature.

15. It is important to note that Yap and Saha 2013 find that heritage plays an influential role in bringing tourists to a country, however, heritage factors are not taken into consideration as heritage factors are mainly time-invariant, and hence absorbed by the fixed effects.

16. In this paper, only the FE results are reported. We have also conducted the RE estimation and the results are available upon request from the authors.

17. This result is consistent with the finding in Su and Lin 2014. 
18. The impact of civil liberties on TA of value $7.39 \%$ is obtained by multiplying the CL coefficient $(0.0739)$ by $100 . \frac{\partial \ln (T A)_{i t}}{\partial C L_{i t}}=0.0739$, Or, $\frac{\partial T A_{i t}}{\partial C L_{i t}} * \frac{1}{T A_{i t}} * 100=0.0739 * 100=7.39 \%$.

19. The positive effect of economic freedom is in the line with Das and Dirienzo 2009 which shows that countries that enjoy higher levels of economic freedom tend to be more competitive in the tourism industry.

20. EXCHR is expressed in terms of the U.S. dollar; an increase in U.S. dollar value means a depreciation of the destination country’s currency.

21. The main results associated with the interaction between CL and EFW are very similar to those of CL and EF. The results are available upon request from the authors.

22. The results are available upon request from the authors.

23. Overall, adding the square terms of CL and EF does not show significant improvement of the modelling result in terms of the adjusted Rsquare (comparing to Table 3).

24. The main finding regarding the effects of CL and EF to inbound tourism is essentially the same regardless of including GDP as a control or not. 
25. The estimated coefficients of human development index (HDI), exchange rate change and inflation are all significant and with the expected signs: positive for HDI and exchange rate change and negative for inflation. This is in line with better quality (higher HDI) and lower cost (higher exchange rate change (depreciation) and lower Inflation) which attract more inbound tourism.

26. In GMM estimation, $\ln ($ GDPPC) is treated as an endogenous variable and instrumented with lagged saving (per capita), investment (percentage of GDP) and secondary school enrolment. In all cases, the existence of serial correlations is tested using AR tests and the results confirm no sign of autocorrelation (at the 5\% level). Moreover, The Hansen test shows that the exogeneity hypothesis (of instruments) cannot be rejected at the $5 \%$ level.

27. The partial effects are based on the equation: $\ln \left(T D_{i t}\right)=\theta_{t}+\beta_{1} C L_{i t}+\beta_{2} E F_{i t}+\beta_{3}\left(C L_{i t}-\mu_{1}\right) *\left(E F_{i t}-\mu_{2}\right)+\gamma Z_{i t}+v_{i}+e_{i t}$ where $\mu_{1}$ and $\mu_{2}$ take values from minimum to maximum values of the political and economic freedom indices, respectively. The coefficient $\beta_{1}$ measures the partial effect of civil liberties when $\mu_{2}$ takes the value from minimum to maximum values for the economic freedom index. A similar interpretation applies to coefficient $\beta_{2}$ as that for $\beta_{1}$. 